\title{
Wojciech Szymański
}

Uniwersytet Warszawski

\section{Hysteria virilis? Polska historia i histeria Wielkiej Wojny ${ }^{1}$}

\section{Abstract \\ Hysteria Virilis? Polish History and Hysteria the Great War}

The article's aim is to provide a critical analysis of the cultural memory of the Great War in Poland which emerged during the war and just after the conflict, as well as the mechanism of its production. The masculinist, heroic, brave - always heterosexist - and picturesque vision of the war, described by Maria Janion as "the Uhlan western," that dominated both the official and collective war memory consitutes a critical point of departure for the introduction of another version of the Great War memory in Poland. This version, contrary to the official one, is rather antiheroic and traumatic, and might be read as a kind of counter-narrative that goes against the official ways of conceptualising the Great War. The article also discusses the role and mechanism of the "war rumour," which was identified by Marc Bloch in his study Réflexions d'un historien sur les fausses nouvelles de la guerre by means of applying it to selected life narratives from the Eastern Front - in particular to memoirs and diaries written by male participants of the Great War. The French historian was particularly interested in how lying affected the psychology of war witnesses, how the witnesses constructed stories about the war events which they had participated in or observed, as well as how rumours contributed to the birth of a mass psychosis and hysteria. An in-depth scrutiny of several

${ }^{1}$ Badania zostały sfinansowane ze środków Narodowego Centrum Nauki przyznanych w ramach finansowania stażu po uzyskaniu stopnia naukowego doktora na podstawie decyzji numer DEC-2014/12/S/HS2/00385. 
texts written in Polish during the war will also facilitate an identification of another, i.e. gendered, racial, and class, aspect of the "false news" which Bloch ignored: namely, its role in the creation of male hysteria. One could risk a claim that the relationship between war rumours and male hysteria is a major feature of the war narratives that are discussed in this article. These are narratives, one should note, which have been erased from the official memory of the Great War and substituted by a heterosexist, masculinist tale about brave and rational soldiers and - here is another lie - about irrational and hysterical women, civilians, and Jews.

Słowa kluczowe: męska histeria, I wojna światowa, wystawy sztuki legionowej, szok artyleryjski, front wschodni, polska pamięć kulturowa

Keywords: hysteria virilis, the Great War, Polish Legions' art exhibitions, shell shock, Eastern front, Polish cultural memory

\section{Historia virilis}

W środę 26 września 1917 roku w „Gazecie Lwowskiej” na tej samej, czwartej, stronie ukazały się dwa krótkie i banalne teksty na tematy bieżące. W kontekście kulturowej historii I wojny światowej, jakiej drobny fragment będzie mnie tutaj interesował, oba te dokumenty stanowią jednak ciekawe świadectwo istnienia sto lat temu w polskim uniwersum kulturowym dwóch komplementarnych i konkurencyjnych względem siebie zarazem - sposobów konstruowania narracji na temat wojny. Ówczesne współistnienie dwóch rodzajów opowieści wojennych jest tym bardziej fascynujące w kontekście powojennego dyskursywnego spreparowania jednej tylko oficjalnej narracji o wojnie, do jakiego doszło w Polsce i który - za Marią Janion oraz licznymi badaczami i badaczkami podejmującymi jej rozpoznania - określał będę mianem ,ułańskiego westernu" 2 .

Ta, jak przypomina Monika Szczepaniak, dyskursywna rama służąca konstrukcji postromantycznego - literackiego i wizualnego - obrazu Wielkiej Wojny, została według Janion stworzona na podstawie takich tekstów dziewiętnastowiecznej kultury polskiej, jak Pieśni Janusza Wincentego Pola, historyczne malarstwo batalistyczne i rodzajowe Juliusza Kossaka i proza historyczna Henryka Sienkiewicza ${ }^{3}$. Składała się więc na nią, oględnie mówiąc, akademicka i tradycyjna, wypracowana jeszcze w ubiegłym wieku, konwencjonal-

${ }^{2}$ M. Janion, Wojna i forma [w:] eadem, Płacz generała. Eseje o wojnie, Warszawa 1998, s. 36-43. O „romantyczno-ułańskim micie radości” pisze zaś Robert Traba. Zob. idem, Zapomniana wojna. Wydarzenia lat 1914-1918 w polskiej i niemieckiej pamięci zbiorowej [w:] Polacy i Niemcy. Historia - kultura - polityka, red. A. Lawaty, H. Orłowski, Poznań 2003, s. 64.

${ }^{3}$ M. Szczepaniak, Habitus żotnierski $w$ literaturze i kulturze polskiej $w$ kontekście Wielkiej Wojny, Kraków 2017, s. 70. 
na i realistyczna forma, za pomocą której - zarówno w sztukach pięknych, jak i literaturze - odmalowywano heroiczną i ofiarną, od początku do końca niepodległościową, wzniosłą i piękną historię Wielkiej Wojny. Ta swego rodzaju fabrykacja patriotycznego i olśniewającego obrazu Wielkiej Wojny polegała na „podstawieniu” oddziału ułanów, którzy „przybyli pod okienko” w miejsce zburzonych i spalonych doszczętnie wsi i miasteczek w dawnym Królestwie Polskim ${ }^{4}$ oraz niewysłuchanego świadectwa trzech i pół miliona uchodźców z historycznych ziem polskich, z których po wojnie z głębi Rosji do domów powrócił nieco ponad milion ${ }^{5}$. W miejsce zaś polifonicznych, nierzadko traumatycznych opowieści trzech milionów rekrutów polskich walczących w niemieckich, austriackich i rosyjskich mundurach na wszystkich głównych frontach I wojny światowej ${ }^{6}$ podstawieni zostali ,chłopcy malowani”. To właśnie ich portrety wykonywane przez powołanego do c. i k. armii Wojciecha Kossaka i innych artystów malarzy służących w sformowanych przy jej boku Legionach Polskich stały się oficjalnym obrazem wojny. W ten sposób skonkretyzowane w obrazie i słowie doświadczenie kilkunastu tysięcy osób służących w tej formacji zbrojnej ${ }^{7}$ zastąpiło nierzadko niewysłowione

${ }^{4}$ Chociaż teren zaboru rosyjskiego został najbardziej doświadczony przez działania wojenne i to tam właśnie wycofujące się wojska rosyjskie stosowały taktykę spalonej ziemi, w ruinie znalazła się także spora liczba miejscowości galicyjskich, dla których paradygmatyczny może być przykład doszczętnie wręcz zburzonych Gorlic. Więcej na ten temat zob. J. Lewicki, Regulacja i odbudowa miast Galicji jako źródto nowoczesnej teorii urbanistycznej w Europie Środkowej [w:] Odbudowy i modernizacje miast historycznych w pierwszej połowie dwudziestego wieku w Europie. Naród, polityka, społeczeństwo, red. I. Barańska, M. Górzyński, Kalisz 2016, s. 107-140.

${ }^{5}$ Zob. A. Prymaka-Oniszk, Bieżeństwo 1915. Zapomniani uchodźcy, Wołowiec 2016, s. 12, 255.

${ }^{6}$ Zaproponowana tutaj przeze mnie liczba nie jest jedyną, jaka pojawia się w opracowaniach historycznych przy próbach liczenia polskich rekrutów na Wielką Wojnę. W opracowaniach zazwyczaj pojawia się zakres od 1 do 3,5 miliona żołnierzy. Na temat problemów i rozbieżności w interpretacji liczby polskich rekrutów na Wielką Wojnę pisze obszerniej Marcin Jarząbek. Zob. idem, Legioniści i inni. Pamięć zbiorowa weteranów I wojny światowej w Polsce i Czechosłowacji okresu międzywojennego, Kraków 2017, s. 32-35.

${ }^{7}$ Wacława Milewska i Maria Zientara zwróciły uwagę, że przez cały okres istnienia Legionów przez formację przewinęło się około dwadzieścia pięć tysięcy żołnierzy i żołnierek. W Legionach znalazło się ponad 180 artystów, z których wielu w okresie międzywojennym sprawowało najwyższe urzędy państwowe, np. Edward Śmigły-Rydz. Zob. eaedem, O ikonografii sztuki legionowej [w:] Przed wielkim jutrem. Sztuka 1905-1918. Materiały Sesji SHS, Warszawa, październik 1990, red. T. Hrankowska, Warszawa 1993, s. 177. Tomasz Nałęcz z kolei zauważył, że w żadnej innej armii na świecie żołnierze „,nie przeczytali tylu książek, nie napisali tylu dzienników, nie wydali tylu okopowych gazetek i jednodniówek, co żołnierze Legionów". Idem, Pokolenie Józefa Piłsudskiego [w:] Legenda Legionów. Opowieść o Legionach oraz ludziach Józefa Pitsudskiego, red. W. Sienkiewicz, Warszawa 2008, s. 343. 
i nieprzedstawione przeżycia milionów ${ }^{8}$. Co ciekawe i warte osobnego, pogłębionego studium, te oniemiałe miliony uwierzyły w elitarną i ekskluzywną wersję opowieści o wojnie, którą określić można mianem nie tyle wojennej, ile legionowej i która pod względem formy i treści pokrywa się zasadniczo ze wspomnianym właśnie „ułańskim westernem”.

To jej świadectwo właśnie znajduje się we wzmiankowanym lwowskim dzienniku. W artykule zatytułowanym Echa uroczystości legionowej czytamy, że ,[z] okazji otwarcia Wystawy Legionowej w ubiegłą niedzielę, wysłano [...] na wniosek prof. dr. Antoniewicza depesze do pułkownika [Zygmunta] Zielińskiego i prof. Mycielskiego"". Zorganizowana przez lwowską delegaturę Naczelnego Komitetu Narodowego wystawa sztuki legionowej, którą otworzono w miejskim Towarzystwie Przyjaciół Sztuk Pięknych, była ostatnią podczas wojny na ówczesnych ziemiach polskich ekspozycją z zainicjowanego jeszcze w 1915 roku przez Jerzego Mycielskiego i Jana Bołoza-Antoniewicza cyklu $^{10}$. W dwóch cytowanych przez „Gazetę Lwowską” depeszach uwidaczniają się charakterystyczne dla heroicznej i niepodległościowej polskiej narracji wojennej motywy. Czytamy więc o „najszlachetniejszym przedstawicielu cnót żołnierskich”, „karności wobec narodu”, a także o „,zbiorowym hołdzie polskiej sztuki dla rycerskich dzieł polskiego oręża""11.

Jeśli sięgnąć by do towarzyszącego wystawie katalogu, odnaleźć w nim można podobny ton i zbliżoną dykcję. W słowie wstępnym autorstwa Mariana Kowarza, które poprzedza katalog przeszło czterystu pokazanych na wystawie artefaktów, czytamy:

Naród polski utrwalał zawsze przez natchnione dzieła najlepszych swych synów wiekopomne chwile swej tak sławnej i tak bohaterskiej historii, więc i Legiony dzisiejszej doby musiały znaleźć twórców, którzy by dzieje tego polskiego, heroicznego czynu i jego całego romantyzmu potomności w wieczną przekazali całość. [...] [Julian] Fałat, [Jacek] Malczewski, [Leon] Wyczółkowski, [Józef] Mehoffer, [Wojciech] Kossak, [Zygmunt] Rozwadowski, [Stanisław] Lentz, [Jan] Rembowski, [Henryk] Uziembło, [Stanisław] Janowski i tylu, tylu innych w godowy

${ }^{8}$ Por. R. Kaczmarek, Polacy $w$ armii kajzera na frontach pierwszej wojny światowej, Kraków 2014, s. 10-26.

9 Echa uroczystości legionowej, „Gazeta Lwowska”, 26.09.1917, nr 219, s. 4. Ortografię i interpunkcję uwspółcześniono.

${ }^{10}$ Wcześniejsze odsłony wystawy sztuki tworzonej przez żołnierzy Legionów Polskich odbyły się w Krakowie, Warszawie, Lublinie, a także w Zurychu, Bernie i Bazylei, Baden i Wiedniu. Por. W. Milewska, M. Zientara, Sztuka Legionów Polskich i jej twórcy 19141918, Kraków 1999, s. 350-355.

${ }^{11}$ Echa uroczystości Legionowej..., s. 4. 
mundur przystroili żołnierza polskiego i zwartym ordynkiem stanęli w kresowym grodzie na przegląd, na podniesienie ducha i pociechę rodaków ${ }^{12}$.

Jak widać, wszystkie najistotniejsze elementy wyróżniające ,ułański western" - z dzikim Wschodem w miejsce dzikiego Zachodu - zostały tutaj zamieszczone. Wojna rysuje się więc jako „,bohaterska historia” i „,czyn heroiczny". Jest kresowy, ukrainny romantyzm, postromantyczne sienkiewiczowskie podnoszenie ducha, jest także i Kossak - Wojciech co prawda, nie Juliusz z konwencjonalnymi obrazami, których tytuły odnajdujemy w katalogu: Portret wachmistrza Tadeusza Buszczyńskiego, Partyzantka, Posterunek obserwacyjny ${ }^{13}$ i które namalować mógłby jego ojciec ${ }^{14}$. Pojawiają się i inni artyści z masą malarskich oraz rzeźbiarskich portretów kolegów żołnierzy oraz przełożonych (,Kramsztyk Roman, Ppułk. Leon Barbecki, olejny, Laszczka Konstanty, Bryg. Józef Piłsudski, bronz."15), scenami rodzajowymi przedstawiającymi wojnę jako męską i piękną przygodę (capstrzyki, podchody, pikiety) oraz rzewnym malarstwem pejzażowym - ,Za Siedlcami w czarnym borze, / Przy gościńcu stał dwór biały"16, Żeńcy nad Styrem ${ }^{17}$, Opactwo w Sieciechowie ${ }^{18}$, Motyw pejsażowy z Rarańczy ${ }^{19}$.

Cytowany tekst katalogowy nie tylko poświadcza istnienie trzech, rozpoznanych przez Janion i wyeksponowanych przez Szczepaniak, konstytutywnych dla dyskursu ,ułańskiego westernu” motywów intertekstualnych i interwizualnych, odwołujących się do twórczości kolejno: Sienkiewicza, Juliusza Kossaka i Pola. Zawiera on również, kluczowy dla moich dalszych rozważań na temat tytułowej męskiej histerii, rodzaj narracyjnego naddatku, który powoduje, że tekst ten ,zdradza się”, ujawniając inny jeszcze, zasadniczy dla konstrukcji „ułańskiego westernu”, element. Zauważmy bowiem, że zmilita-

${ }^{12}$ Katalog Wystawy Legionów Polskich. Lwów wrzesień-październik 1917, Lwów 1917, s. 7.

13 Ibidem, s. 17.

${ }^{14}$ Można powiedzieć, że syn, malując inne mundury i elementy uzbrojenia, uaktualniał po prostu historyczne sceny batalistyczne i rodzajowe ojca, jak również swoje wcześniejsze kompozycje osadzone w rzeczywistości historycznej Księstwa Warszawskiego. Więcej na temat tego malarstwa jako traumatycznego reperformansu XIX wieku pisałem w: W. Szymański, Images from the Eastern Front. Great Returns or Death among Old Decorations? Remarks on Representation of the Great War in Polish Art [w:] Conflicting Discourses, Competing Memories: Commemorating the First World War, red. A. Branach-Kallas, N. Sabiniarz, N. Strehlau, Torun 2015, s. 15-37.

${ }^{15}$ Katalog Wystawy Legionów Polskich..., s. 18.

${ }^{16}$ W. Pol, Kłopot pannom z czwartakami [w:] idem, Pieśni Janusza, Kraków 1921, s. 81.

${ }^{17}$ Katalog Wystawy Legionów Polskich..., s. 19.

18 Ibidem, s. 17.

19 Ibidem, s. 16. 
ryzowani faktycznie i dyskursywnie artyści-żołnierze biorący udział w wystawie (,zwartym ordynkiem stanęli”) „,w godowy mundur przystroili żołnierza polskiego”. Co to oznacza, wypada zapytać? Czym był i jak wyglądał „,godowy mundur" żołnierza polskiego? Z jednej strony wszyscy przecież dobrze pamiętamy słowa pieśni legionowej, według której „Nie noszą lampasów, lecz szary ich strój, / Nie noszą ni srebra, ni złota". Z drugiej zaś równie dobrze wiemy, czym jest przybierana w okresie rozrodu przez niektóre zwierzęta szata godowa. I tutaj właśnie pojawia się epistemiczne wahanie. Obie przesłanki (1) szary, zgrzebny uniform oraz (2) godowa jaskrawość barw z trudem przystają do wizji godowego munduru legionów. Nie o sam wygląd i formę mundurów oraz ich malarską reprezentację chodzi zatem w użytej w katalogu wystawy przenośni.

Metafora ta ujawnia prymarną wobec wojennej opowieści w konwencji „ułańskiego westernu” kulturową treść: Wielka Wojna to okres godów, podczas których należy uwieść i posiąść Polskę, która funkcjonuje tutaj jako figura pożądania. Oczywisty problem, jaki rysuje się w takim odczytaniu, to spowodowana nieistnieniem niepodległego państwa nieobecność samego obiektu pożądania. Jak bowiem zauważyła Szczepaniak:

Polska męskość militarna konstytuuje się w oderwaniu od państwa - w cieniu silnych zaborców i ich hegemonicznych męskości, stanowi jednak kontynuację tradycji narodowej o zabarwieniu heroicznym, odzwierciedlającą mentalne struktury długiego trwania ${ }^{20}$.

Chociaż więc nieobecna Polska może być z powodzeniem wizualizowana - np. pod postacią alegorycznej, kobiecej Polonii - jej faktyczny brak sprawia, że jest ona raczej fantazmatycznym obiektem pożądania, nie zaś rzeczywistością. „Godowe stroje” samców włożone zostały więc przedwcześnie i nieco na wyrost, a erotyczne spełnienie projektowane jest $\mathrm{w}$ tych uniformach pod nieobecność kobiecego przedmiotu pożądania, który co najwyżej być może zjawi się po wojnie. Mamy więc w wypadku „ułańskiego westernu” do czynienia raczej z autoerotyzmem niż rzeczywistym spełnieniem, które jest, by tak rzec, rzeczą przypadku i zaistnieje post coitus, jeżeli Polska zjawi się po wojnie. Ta sytuacja historyczna - przepisana tutaj jedynie na relacje psychoseksualne - sprawia, że po pierwsze, ,ułański western” jest w istocie antyopowieścią przygodową o wojnie, anty-Iliada, w której istnienie pięknej Heleny jest co najwyżej implikowane. A zatem, po drugie, nie jest on ,prawdziwą" męską przygodą, a co najwyżej chłopięcą zabawą w przygodę. Po trzecie w końcu, jego literackie i wizualne reprezentacje, jeżeli mają podtrzymać wiarę w jego „westernowy” i przygodowy charakter, muszą być obrazami ukazującymi - konstruującymi w zasadzie - heroiczną męskość ich bohaterów.

${ }^{20}$ M. Szczepaniak, op.cit., s. 11. 
Konstruowanie takiej - militarystycznej i normatywnej - męskości, której obraz przystaje do heroicznej i patriotycznej zarazem opowieści wojennej, odbywa się, jak przypomina Wojciech Śmieja, na trzech poziomach. „Od Élisabeth Badinter wiadomo - że tradycyjnie pojmowana męskość opiera się na trzech zaprzeczeniach”21 : „mężczyzna musi dowieść, że jest mężczyzną, zaprzeczając byciu kobietą, dzieckiem i homoseksualistą"22. Zauważmy, że cechy tej heroicznej i patriotycznej męskości zawarte zostały właśnie w metaforze „godowych strojów”. Po pierwsze, godowe szaty przybiera zazwyczaj samiec, nie zaś samica. Po drugie, gody jako rytuał nastawiony na prokreację są ex definitione aktem heteroseksualnym. Po trzecie zaś, biorą w nich udział tylko osobniki dojrzałe płciowo, a zatem nie dzieci. W obliczu nieobecności oblubienicy-Polski, te gody nie były oczywiście tak jednoznaczne, a noszenie „godowego munduru”, nie gwarantując statusu „prawdziwego” mężczyzny, było, by się tak wyrazić, strojeniem się w cudze piórka. Otwarte na razie pozostawiam pytanie, czym skutkowałoby zdemaskowanie tej swego rodzaju męskiej i heteroseksualnej maskarady.

Drugi tekst z „Gazety Lwowskiej” utrzymany został w zupełnie innej niż pierwszy poetyce. Jest bowiem anonsem zapowiadającym przedstawienie zatytułowane Marionetki pokojowe, mające się odbyć za dwa dni, w piątek, w sali Towarzystwa Muzycznego. Czytamy:

Premiera tej zabawnej imprezy, która jak tamtegoroczne Marionetki wojenne cieszyć się będzie napewno znacznym powodzeniem [...]. Pełen humoru i łagodnej satyry tekst, pióra literatów lwowskich, świetne figurki wykonane przez art. rzeźbiarza [Zygmunta] Kurczyńskiego i wykonawca p. [Ludwik] Lateiner-Lawiński wszystko to tworzy całość, którą niejeden zachce zobaczyć. Bilety wcześniej do nabycia w księgarni H. Altenberga w hotelu George' $a^{23}$.

Oba wspomniane w cytowanym anonsie przedstawienia lalkowe, będące intermedialnym dziełem o charakterze performatywnym ${ }^{24}$, tematyzowały

${ }^{21}$ W. Śmieja, Hegemonia i trauma. Literatura wobec dominujących fikcji męskości, Warszawa 2016, s. 62.

${ }^{22}$ Ibidem, s. 62-63.

${ }^{23}$ „Gazeta Lwowska”, 26.09.1917, nr 219, s. 4. Ortografię i interpunkcję uwspółcześniono.

${ }^{24}$ Pisząc o intermedialności obu ludycznych utworów, mam na myśli ich charakter sceniczny, jak również plastyczny (twarze lalek wykonane przez Kurczyńskiego traktować można jako rzeźby) i literacki (tekst Marionetek wojennych ułożony został przez Henryka Zbierzchowskiego, Artura Schrödera i Stanisława Wasylewskiego oraz wydany pod pseudonimem Henartstan, Marionetki pokojowe zaś opublikowano pod pseudonimem Hestan, co wskazuje na współautorstwo Zbierzchowskiego i Wasylewskiego). Nie bez znaczenia pozostają też elementy muzyczne, gdyż kwestie wypowiadane przez Lawińskiego były przerywane piosenkami wykonywanymi na rozmaite, popularne wówczas melodie. 
wojenną rzeczywistość w stolicy ciągle jeszcze istniejącej Galicji, głównie zaś nieobecne $\mathrm{w}$ oficjalnych obrazach wojny pokazywanych we lwowskim Towarzystwie Przyjaciół Sztuk Pięknych kłopoty z aprowizacją, spekulację cenową, niepewność oraz głód. Komiczna perspektywa, z której ogląda się tutaj wojnę i mówi o niej, była raczej cywilna niż wojskowa. Co prawda, wśród bohaterów obu utworów są także urlopowani legioniści, jak również Juliusz Leo i Władysław Leopold Jaworski, pierwszy i drugi prezes Naczelnego Komitetu Narodowego, organizacji sprawującej przecież zwierzchność nad Legionami ${ }^{25}$, z ramienia której urządzono lwowską wystawę. Mimo to „ułański western", jeżeli w ogóle pojawia się w obu utworach, to raczej jedynie przez pryzmat pojedynczych rekwizytów czy też akcesoriów, za pomocą których jesteśmy go wprawdzie w stanie rozpoznać, ale nie umiemy już/jeszcze ${ }^{26} \mathrm{w}$ niego uwierzyć. Lektura obu utworów scenicznych dowodzi także, że wbrew temu, co w katalogu pisał Kowarz, ,,rodacy” nie potrzebowali wystawy legionowej, by się pocieszyć; to bowiem skutecznie robili i bez niej.

Komizm w obu utworach nie jest wprawdzie wysokiego lotu, lecz nie jego jakość mnie tutaj interesuje. Marionetki chcę bowiem odczytywać nie tylko jako komplementarną wobec legionowego „ułańskiego westernu” narrację o wojnie, lecz przede wszystkim jako rodzaj kontrhistorii, której kontrfaktyczność ujawnia się na dwóch poziomach. Po pierwsze, na poziomie wyboru tematów, których zabrakło na wystawie i które do patriotycznego i heroicznego kanonu reprezentacji dodawały zupełnie przyziemne z punktu widzenia ułanów/kowbojów kwestie istotne dla ludności cywilnej. Po drugie, na poziomie całościowego odrzucenia niepodległościowo-bohaterskiej narracji NKN-u, która dodatkowo zostaje tutaj nie tylko osłabiona wprowadzeniem „cywilnych" tematów, lecz także zdekonstruowana specyficznym przywołaniem takich motywów, które Komitet usiłował za pomocą kolportowanej przez siebie sztuki i literatury wzmacniać i mitologizować ${ }^{27}$.

Oczywiście, w myśl „odkrytej” już zasady organizującej strukturę ,ułańskiego westernu” w ,godowym mundurze”, który okazał się tyleż niepodległościowym i bohaterskim czynem, co operacją stwarzania reprezentacji mę-

${ }^{25}$ M. Drozdowski, Naczelny Komitet Narodowy (1914-1918). Polityczne i organizacyjne zaplecze Legionów Polskich, Kraków 2017, s. 85-149.

${ }^{26}$ Piszę ,już/jeszcze”, mając na myśli późniejszą kanonizację ułańskiego westernu oraz jego status oficjalnej i jedynej narracji wojennej.

${ }^{27}$ NKN poza organizacją wystaw posiadał drukarnie i składy księgarskie, gdzie kolportowano zamawiane przez kierownictwo druki o charakterze patriotycznym, obrazy pokazywane na wystawach były zaś powielane w formie kart pocztowych i druków propagandowych. Więcej na ten temat w kontekście performatywności wystaw sztuki legionowej i wytwarzania dominującej, legionowej raczej, nie zaś wojennej wizji Wielkiej Wojny piszę w: W. Szymański, „Modi memorandi”. Pamiętanie i przeżywanie Wielkiej Wojny wtedy i dzisiaj. Próba komparatystyczna, „Litteraria Copernicana” 2018, nr 3 (27), s. 27-42. 
skiego, heteroseksualnego i dojrzałego mężczyzny, najbardziej interesujące wydają się te momenty Marionetek, które ten jednoznaczny, lecz kruchy obraz destabilizują i rozchwiewają.

Tyleż mglisty, co fantazmatyczny obiekt pożądania w niepodległościowo-heroicznym dyskursie legionowym - Polska - w Marionetkach zastąpiona zostaje przyziemną ideą pokoju, a niezaspokojone ułańskie pożądanie zostaje tutaj wymienione na równie niespełniony popęd jedzenia. Bohaterowie Marionetek, którzy poza postaciami znanymi publicznie rekrutują się z lwowskich klas niższych, marzą: „W wojennym, twardym znoju / Gdy wciąż kłopoty drą cię, / Marzymy o pokoju, / Lecz z wiktem i - na froncie"28. Polska, chociaż jej możliwość rysuje się za horyzontem, nie jest idée fixe, którą żyliby lwowianie: „Nim się stworzy Polska / W Jagiełów granicy, / Zrobiłyśmy sklepik / Przy Fredry ulicy. / Dla sprawy ojczystej / Praca wre bez przerwy, / Ogórek sześć centów, / I świetne konserwy", śpiewa Pani z puszką ${ }^{29}$. Brak w Marionetkach centralnej dla dyskursu legionowego alegorii Polonii, która zastąpiona zostaje tutaj wykutą z salcesonu alegorią Aprowizacji. Tak mówi o niej jej twórca, Zygmunt Kurczyński:

Mam pewną ideę śliczną: / Trochę symbolu a trochę groteski - / Chcę bowiem wykuć grupę à la Jacek Malczewski. [...] Nie w marmurze ani glinie, / Gips tu nie utrafi tonu, / Rzecz ma szeroko zasłynie / Będzie bowiem (mlaska językiem) z salcesonu! [...] U stóp cokołu dywan usłany / Z kaszy hreczanej, / Z niej zaś ciekawie wychylają głowę / Karty tłuszczowe, chlebowe, cukrowe. / Kobieta boskiej pełna krasy, / Przybrana w wieniec kiełbasy / Smaruje masłem chleb biały ${ }^{30}$.

Rzeczywistość frontowa, poddawana dyskursywnej obróbce z okazji kolejnych wystaw legionowych, w naznaczonym niedoborami świecie Marionetek okazuje się cywilnym grepsem, w którym pozostało niewiele miejsca na heroizm i wojenne podniecenie. I tak dowiadujemy się, że „Pierwsza bitwa pod Isonzo / Była interesującą. / Lecz co tu zrobić u czarta / Gdy przyjdzie czterdziesta czwarta?"'31. Sławna bitwa pod Gorlicami natomiast funkcjonuje w tym świecie nie jako najważniejsze i najkrwawsze starcie w Galicji, dzięki któremu Lwów został oswobodzony od wojsk rosyjskich, lecz, jak dowiadujemy się z ust seksworkerki Panienki, jako synonim niezapomnianego i wyuzdanego stosunku seksualnego: „Wiozę miłość mą gorącą / Do Brzeżan i nad Izonco, / Bo mnie przecież nie odtrącą [...]. Chociaż ciężkie masz haubice/

${ }^{28}$ Hestan, Marionetki pokojowe. Trzy akty wesolych piosenek $i$ aktualnych dialogów, Lwów 1917, s. 6.

${ }^{29}$ Ibidem, s. 12-13.

${ }^{30}$ Henartstan, Marionetki wojenne, Lwów 1917, s. 68-69.

${ }^{31}$ Hestan, op.cit., s. 6. 
[...] Zaraz zrobię ci Gorlice”32. Legionowe „gody w mundurze” tracą swą heteroseksualną jednoznaczność, kiedy na scenie zjawia się malarka i feministka, partnerka nieżyjącej już wówczas Marii Konopnickiej, Maria Dulębianka. Przyłapawszy na pocałunkach dwóch członków NKN-u, Ignacego Daszyńskiego oraz Juliusza Leo, wprost kwestionuje ona preparowaną z takim trudem i konsekwencją męskość uczestników „ułańskiego westernu”, mówiąc piskliwie: „Gwałtu dwie męskie dusze znów do pralni / Oddać by trzeba, by wyprać je z brudu. / dwaj wielcy 'proszę pani' - wodze ludu - / No, a uściskali się - to najfatalniej, / Całkiem jakby homoseksualni"”33.

Reasumując, należy stwierdzić, że intermedialne, ludyczne, niepoprawne Marionetki wprawdzie już nie śmieszą, pozostają jednak dokumentem o szczególnym znaczeniu dla kulturowej rekonstrukcji polskich obrazów I wojny światowej. Pojawiają się w nich tematy zupełnie wyparte i nieobecne w ,ułańskim westernie", który po wojnie stał się oficjalną historią tamtego czasu. Gdyby głód, niepewność jutra, strach itd. pojawiały się w „westernowych” narracjach o Wielkiej Wojnie na takich samych prawach, co tematy heroiczne, spowodowałoby to nieuchronny rozpad zarówno samego dyskursu, jak i jego męskiego podmiotu. Historia, parafrazując Haydena White'a, ujawniłaby swoją histeryczną podstawę $e^{34}, \mathrm{a}$, ułański western” straciłby swoją gatunkową czystość i niewinność.

\section{Hysteria virilis}

Przywołany właśnie amerykański historyk na temat związku pomiędzy historią a histerią wypowiada się następująco:

Istnieje podobieństwo między sposobem, w jaki historycy rozumieją relację pomiędzy przeszłością historyczną i teraźniejszością [...] a Freudowską koncepcją związku między traumatycznym wydarzeniem w życiu jednostki i jego ,,powrotem”, czemu towarzyszy tak silny wstrząs, że jednostka przestaje normalnie funkcjonować ${ }^{35}$.

Jak przypomina dalej White, pojęcie traumatyzującego zdarzenia umożliwia Sigmundowi Freudowi:

\footnotetext{
${ }^{32}$ Henartstan, op.cit., s. 79.

${ }^{33}$ Ibidem, s. 34-35.

${ }^{34}$ Por. H. White, Zdarzenie historyczne, przeł. R. Borysławski [w:] idem, Proza historyczna, red. E. Domańska, Kraków 2009, s. 279.
}

${ }^{35}$ Ibidem, s. 277. 
wysunąć teorię ,ukrytej historii” jednostki, analogicznie, całego narodu bądź ludu, wobec której ,oficjalna”'wersja jego przeszłości musi być rozumiana jako alibi lub sublimacja, która pojawiła się w odpowiedzi na poczucie winy wzbudzone przez pierwotny $\mathrm{akt}^{36}$.

Powyższe rozpoznania z łatwością, jak sądzę, przełożyć można na dwie wyśledzone na jednej stronie „Gazety Lwowskiej” wersje opowieści o Wielkiej Wojnie w kulturze polskiej: oficjalną oraz ukrytą. Miejsce oficjalnej zajmowałby oczywiście w takim układzie ,ułański western”, rolę ukrytej zaś i wypartej z czasem historii, sceniczne teksty Marionetek. W takiej optyce oficjalna - legionowa - opowieść o wojnie okazuje się rekompensacyjną komedią sublimacji ${ }^{37}$, przysłaniającą doświadczenie pierwotne i rzeczywiste, niemożliwe do wyrażenia bez jednoczesnego unieważnienia dyskursu „ułańskiego westernu". Odkrycie tego doświadczenia, które White nazywa za Freudem wydarzeniem traumatycznym, nierozerwalnie łączy się z historią Wielkiej Wojny, jak również z męską histerią.

Fakt znamienny dla tych rozważań: histeria, co wielokrotnie było już tematem akademickich rozważań, narodziła się jako „,kobieca choroba" ${ }^{38}$ i jako taka była przypisywana kobietom oraz zniewieściałym mężczyznom przez medycynę i kulturę przynajmniej od końca XIX wieku i przełomowych badań Jeana-Martina Charcota ${ }^{39}$, u którego w latach 1885-1886 terminował sam Freud ${ }^{40}$. I chociaż właśnie w trakcie Wielkiej Wojny rozwijały się medyczne, psychologiczne i kulturowe studia na temat histerii, które zaczęły łączyć ją teraz z takimi „męskimi chorobami”, jak szok artyleryjski (shell shock), nerwica frontowa, a wreszcie nerwica traumatyczna ${ }^{41}$, opór wobec przypisania histerii mężczyznom był, zwłaszcza w kulturze niemieckojęzycznej, powszechny i ogromny ${ }^{42}$.

Trudno jednoznacznie rozstrzygnąć, czy i w jakim stopniu na polską oficjalną historię wojenną wpłynęła niemiecka niechęć do rozpozna-

${ }^{36}$ Ibidem.

${ }^{37}$ Odwołuję się tutaj do pojęcia zaproponowanego przez Annę Markowską. Por. eadem, Komedia sublimacji. Granica wspótczesności a etos rzeczywistości w sztuce amerykańskiej, Warszawa 2010.

38 Zob. E. Showalter, The Female Malady: Women, Madness and English Culture, 1830-1980, London 1987.

${ }^{39}$ Zob. M.S. Micale, Hysterical Man: The Hidden History of Male Nervous Illness, Cambridge 2008, s. 120.

${ }^{40}$ Zob. F. Cochet, „Les Légendes de la guerre” d'Albert Dauzat, un témoignage à chaud des phénomènes de culture collective [w:] A. Dauzat, Légendes, prophéties et superstitions de la Grande Guerre, Paris 2012, s. 13.

${ }^{41}$ Zob. A. Branach-Kallas, Uraz przetrwania. Trauma i polemika z mitem pierwszej wojny światowej w powieści kanadyjskiej, Toruń 2014, s. 13-15.

${ }^{42}$ Zob. L. van Bergen, Before My Helpless Sight: Suffering, Dying and Military Medicine on the Western Front, 1914-1918, London-New York 2016, s. 394. 
nia męskiej histerii lub niemiecki i austriacki kod kulturowy, który według George'a Mosse'a i Shulamit Volkov stawiał znak równości między Żydami, homoseksualistami i kobietami jako jednostkami i grupami z deficytem moralnej - męskiej - powagi, dlatego podatnymi na histerię ${ }^{43}$. To, co wydaje mi się ciekawsze i istotniejsze od teorii wpływów, to rzeczywiste istnienie w polskim uniwersum kulturowym tych heteroseksistowskich mitów, które istotnie wbudowane zostały w sam kościec „ułańskiego westernu” w godowym mundurze. Traumatyczne i histeryczne opowieści wojenne stanowiły dla tego dyskursu śmiertelne zagrożenie, i to co najmniej z dwu powodów: po pierwsze, ujawniając „ukrytą historię”, która okazywała się wcale nie taka heroiczna i wcale nie taka piękna, jak to sobie ułani wyobrazili; po drugie, umożliwiając histeryczną interpretację samego „ułańskiego westernu” jako tekstu kultury właśnie o charakterze fantazmatycznym, sublimacyjnym i rekompensacyjnym. Ta awersja do histerycznej i traumatycznej korektury polskiej męskości czasu Wielkiej Wojny skutkuje zupełnie nieprawdopodobną z punktu widzenia kulturowej historii lat 1914-1918 nieobecnością w polskim dyskursie szeregu charakterystycznych faktów. Jak bowiem inaczej tłumaczyć chociażby zupełny brak wśród polskich mężczyzn-uczestników Wielkiej Wojny opisywanego szeroko w literaturze zjawiska nerwicy frontowej, której w 1917 roku według statystyk medycznych uległo, na przykład, 25 procent żołnierzy brytyjskich ${ }^{44}$ ?

W dalszej partii niniejszego tekstu chciałbym skupić się na ukazaniu histerii, wypartej z polskiej pamięci I wojny światowej, a przecież powszechnej wówczas w społeczeństwie oraz wśród żołnierzy. Wybrałem dwa teksty o charakterze dokumentu osobistego, które, jak wierzę, nie tylko ukażą istnienie $h y$ steria virilis, lecz także potwierdzą przyczyny jej dyskursywnego wymazania czy, w najlepszym przypadku, przypisania innym. Najpierw chciałbym jednak, zarysowując tło i kontekst, odnieść się do dwóch studiów klasycznych z perspektywy kulturowej historii Wielkiej Wojny. Jako jedne z pierwszych analizowały one warunki pojawienia się męskiej histerii. To napisane już w 1915 roku przez Freuda Aktualne uwagi o wojnie $i$ śmierci oraz wydane zaledwie trzy lata po zakończeniu wojny Rozważania historyka o plotce wojennej Marca Blocha.

Freud rozpoczyna swój tekst od podstawowego także dla Blocha rozpoznania. Wojenny chaos odpowiada za stan ciągłego epistemicznego zawieszenia jednoznacznych sądów i opinii:

Porwani wirem tego czasu wojennego, zdani na jednostronne informacje, bez dystansu do wielkich zmian, które już się dokonały lub zaczynają się dokonywać, nie przeczuwając, co niesie ze sobą formująca się już w zalążku przyszłość, sami

${ }^{43}$ S. Volkov, Antysemityzm i antyfeminizm. Norma społeczna czy kod kulturowy?, przeł. J. Górny, P. Pieńkowska [w:] eadem, Pomyst na nowoczesność. Żydzi niemieccy w XIX i na początku XX wieku, przeł. J. Górny, P. Pieńkowska, Warszawa 2006, s. 62-88.

${ }^{44}$ Zob. A. Branach-Kallas, op.cit., s. 13. 
błądzimy w tym, co się tyczy znaczenia nacierających na nas wrażeń i wartości wydawanych przez nas osądów ${ }^{45}$.

Ta niejednoznaczna zdaniem Freuda sytuacja poznawcza, w jakiej stawia nas wojna, łączyła się w ówczesnym konflikcie z bezprzykładnym okrucieństwem, co groziło traumatycznymi zaburzeniami psychicznymi ${ }^{46}$. Wojna bowiem wpływa na procesy poznawcze, jak również na zdolności do przekazania miarodajnego świadectwa.

Nie inaczej swoją opowieść o wojnie zaczyna Marc Bloch, francuski historyk, jeden z najbystrzejszych umysłów swojej epoki, naoczny świadek i uczestnik walk na froncie zachodnim. Plotkę wojenną Bloch traktuje zgodnie z linią Freuda jako rodzaj zbiorowej psychozy, jaka pojawia się w warunkach ograniczonej wojną dystrybucji prawdziwych informacji ${ }^{47}$. Plotka wojenna, będąca dla Blocha fenomenem psychologicznym, ma według niego niebagatelne znaczenie w procesie konstruowania świadectwa $\mathrm{i}$ - dalej, dla nas tekstowych i wizualnych reprezentacji wojny. Wielka Wojna ukazała mający dalekie konsekwencje fakt i kazała postawić nowe wówczas pytania: „Nie ma dobrych świadków; nie istnieje relacja wiarygodna we wszystkich szczegółach - ale w jakich punktach wypowiadający się ze szczerością świadek, który sądzi, że mówi prawdę, zasługuje na wiarę?"48. Jak widać, od samego początku, kiedy Bloch zdecydował się spisywać swoje uwagi naocznego świadka, zdawał sobie sprawę z trudności, jakie stoją przed każdym, kto chciałby być „dobrym” i „miarodajnym” świadkiem wojny, wydarzeń zrazu niejasnych, widzianych jedynie fragmentarycznie, z jednostkowej perspektywy, w końcu nie w pełni zrozumiałych. Tym, co zainteresowało Blocha, było powstawanie i cyrkulacja plotki wojennej. Zrazu niewinne kłamstwo lub nieporozumienie, powtórzone i przy kolejnych powtórzeniach zwielokrotnione, podkoloryzowane, stawało się żyjącym własnym życiem faktem kulturowym. Badacz cytował niemieckie przysłowie w formie dwuwiersza: „Kommt der Krieg ins Land, / Dann gibt's Lügen wie Sand [Kiedy wojna zawita, / Wtedy kłamstwo rozkwita]" 49 .

Bloch w swoich Rozważaniach skupił się zwłaszcza na dwóch plotkach wojennych, paradygmatycznych dla warunków frontu zachodniego Wielkiej

${ }^{45}$ S. Freud, Aktualne uwagi o wojnie i śmierci, przeł. R. Reszke [w:] idem, Pisma spoteczne, przeł. R. Reszke, A. Ochocki, M. Poręba, oprac. R. Reszke, Warszawa 2009, s. 27.

46 Ibidem, s. 35.

${ }^{47}$ M. Bloch, Rozważania historyka o plotce wojennej [w:] idem, Dziwna klęska, przeł. K. Marczewska, Warszawa 2008, s. 269.

48 Ibidem, s. 271. Skądinąd, stąd trudność, to właśnie histeryk mówi: „Powiem panu to, bo to widziałem". Zob. F. Cochet, op.cit., s. 14.

${ }^{49}$ M. Bloch, op.cit., s. 279. 
Wojny. Pierwsza powstała jeszcze w 1914 roku, a dotyczyła lądowania tysięcy rosyjskich żołnierzy w portach Europy Zachodniej. Plotka ta miała, jak przypomina historyk, dwa warianty:

Wszyscy pamiętamy tę pogłoskę, która w końcu sierpnia 1914 roku przebiegła przez Wielką Brytanię i Francję, jak iskra po płonącym loncie: Rosjanie, według jednych lądujący całymi dziesiątkami tysięcy w portach szkockich, według innych w Marsylii, zasilają szeregi zachodnich sprzymierzeńców ${ }^{50}$.

Oczywiście ani w sierpniu 1914 roku, ani nigdy później w ciągu kolejnych lat wojny, nie doszło do żadnego rosyjskiego desantu czy to w Szkocji, czy na południu Francji. Plotka ta pojawiła się z powodu początkowej psychozy strachu i była wyrazem myślenia życzeniowego. Na jej powstanie zaś wpływ mogli mieć słowiańscy ochotnicy, Rosjanie, Polacy i Czesi, przyjmowani do armii francuskiej i brytyjskiej.

Pogłoska druga, o której pisze Bloch, nie jest tak zabawna i niewinna, jak pierwsza. To niemiecka plotka wojenna, która spowodowała planowy ostrzał artyleryjski, spalenie i zburzenie belgijskiego Lowanium w sierpniu 1914 roku. Jak powszechnie wiadomo, by unicestwić całe miasto, którego zburzenie stało się symbolem niemieckiego barbarzyństwa Hunów w propagandzie wojennej Ententy, wystarczył jeden epizod. Destrukcyjna moc plotki wojennej uruchomiona została po przypadkowej wymianie ognia, do której doszło między żołnierzami belgijskimi a niemieckimi, po której Niemcy zdecydowali się w Lowanium zastosować odpowiedzialność zbiorową, przypieczętowując tym samym los miasta i jego mieszkańców. Po wygnaniu z miasta wszystkich mieszkańców zburzono Lowanium w ostrzale artyleryjskim, gdyż, jak pisały niemieckie gazety, Belgowie obojga płci to żądne krwi bestie, które w zdradziecki sposób atakować miały z ukrycia niemieckich żołnierzy wkraczających do Belgii ${ }^{51}$. Szpiedzy, partyzanci, wolni strzelcy - oto Belgowie. Jak pisze Bloch, niemieccy żołnierze tym chętniej wierzyli w plotkę wojenną, im łatwiej padali ofiarami strachu i histerii:

Długie marsze, nędzne kwatery, bezsenne noce powodowały skrajne wyczerpanie ciał, które nie zdążyły jeszcze przywyknąć do tych ciężkich doświadczeń. [...] „Nerwy są napięte, wyobraźnia rozgorączkowana, poczucie rzeczywistości zachwiane"s2.

Nawet architektura w Belgii, w tym otwory w gotyckich budynkach służące do montowania rusztowań, które zaczęto wyobrażać sobie jako otwory

\footnotetext{
50 Ibidem, s. 286.

${ }^{51}$ Ibidem, s. 289.

52 Ibidem, s. 291.
} 
strzelnicze, utwierdzała Niemców w przekonaniu o wyjątkowej perfidii Belgów przywykłych do wojny partyzanckiej. Jak konstatuje Bloch, plotka padła na podatny grunt, przygotowany już niemal pięćdziesiąt lat wcześniej:

Ludzi tych karmiono opowieściami z wojny 1870 roku, od dzieciństwa nabijano im głowy okrutnymi wyczynami przypisywanymi francuskim wolnym strzelcom, rozpowszechniano te historie w powieściach i obrazach, militarne wydawnictwa udzielały im swoistego oficjalnego poręczenia; niejeden podręcznik z podoficerskiego plecaka poucza, jak należy postępować ze zbuntowanymi cywilami, a zatem na pewno tacy będą. [...] [O]to pradawna materia, która miała dostarczyć legendzie budulca ${ }^{53}$.

Plotka wojenna, „zwierciadło, w którym świadomość zbiorowa ogląda własne oblicze" 54 , istniała naturalnie także w tym czasie na froncie wschodnim Wielkiej Wojny. Interesujący i nasuwający się niejako od razu w kontekście zburzenia Lowanium jest tutaj oczywiście przypadek granicznego i znajdującego się wówczas w Imperium Rosyjskim Kalisza. Zajęty w sierpniu 1914 roku, Kalisz, tak jak belgijskie miasto, został z premedytacją, planowo spalony i wyburzony ${ }^{55}$. Zburzenia Kalisza nie poprzedziła żadna plotka wojenna, jak było to w wypadku Lowanium ${ }^{56}$. Podobnie jak w Lowanium jednak doszło do przypadkowej wymiany ognia: niemieccy żołnierze, najprawdopodobniej zaskoczeni przez spłoszone konie na rynku, zaczęli bezładnie strzelać. Wyrok był taki sam, jak ten, który zapadł na Lowanium.

Incydent ten przywołuję nie tylko, by porównać i skontrastować go z przypadkiem belgijskim. To zdarzenie bowiem zaktualizowało całą serię plotek wojennych dotyczących Niemców i rozpowszechnionych na froncie wschodnim, uruchamiając oprócz obrazów ,,pruskiego bestiarium" ${ }^{57}$ także proces bezładnej zrazu, z czasem zaś planowej, ucieczki ludności polskiej, rosyjskiej, białoruskiej i ukraińskiej ${ }^{58} \mathrm{z}$ terenów Imperium Rosyjskiego zajmowanych

${ }^{53}$ Ibidem, s. 291-292.

54 Ibidem, s. 299.

${ }_{55}$ Dokonało się to na dwa dni przed zburzeniem Lowanium.

${ }^{56}$ Chociaż, co oczywiste, tak jak w wypadku niemieckich wyobrażeń na temat Belgów i Francuzów, istniał zespół uprzedzeń, stereotypów i kliszy, za pomocą których konceptualizowany był Wschód z jego półbarbarzyńskimi, słowiańskimi i żydowskimi mieszkańcami. Por. ,,Niemiecki Wschód”. Wyobrażenia - misja - dziedzictwo, wyb. i oprac Ch. Klessmann, przeł. I. Drozdowska-Broering, J. Kałążny, Poznań 2014.

${ }^{57}$ K. Stępnik, Rekonesans. Studia z literatury i publicystyki okresu I wojny światowej, Lublin 1997, s. 154.

58 Jestem oczywiście świadomy pewnego anachronizmu, jaki zachodzi podczas używania określeń narodowościowych do opisu grup, które w dużej mierze w czasie I wojny światowej nie utożsamiały się ze wspólnotą narodową, identyfikując się częściej np. z wyznawaną konfesją. 
przez armię niemiecką. Tak jak dla Niemców Belgowie byli bestiami, podobnie dla Polaków i Rosjan to Niemcy, jak niosła plotka wojenna wzmocniona wydarzeniami w Kaliszu, stali się uosobieniem czystego zła.

Bogaty katalog plotek wojennych frontu wschodniego, który sporządziła Aneta Prymaka-Oniszk, pochodził głównie od straumatyzowanej strachem ludności chłopskiej uciekającej na Wschód z terenów zajętych przez Niemców i koczującej w lasach, przy dworskich czworakach i we wsiach. Ludzie ci w takich warunkach rozpowszechniali wieści o szczególnym okrucieństwie żołnierzy niemieckich, a te zaczynały żyć własnym życiem ${ }^{59}$. Plotki te zawierały inwentarz tradycyjnego bestialstwa (wsie miały zostać spalone, uciekających chłopów Niemcy łapali i wrzucali w ogień) oraz perfidii i zdeterminowania wroga:

[...] rosyjscy sanitariusze zbierający rannych po bitwie nie byli w stanie pomóc Niemcowi w ciężkim stanie. Ten, gdy „odeszli, podczołgał się, trzymając jedną ręką swe wnętrzności, pod chałupę, powstał i zapałką podpalił słomiany dach. Gdy mu ludzie chcieli przeszkodzić, zaczął strzelać z brauninga. Powlókł się tak samo do drugiej chałupy i do trzeciej. Podpaliwszy trzecią, stracił resztkę sił, »Przewalił się, mówili Kurpie, i zdechł, wciąż przeklinając po swojemu«"60.

Plotki wojenne tego rodzaju były oczywiście wykorzystywane politycz$n^{n i}{ }^{61}$ przez wojenną propagandę rosyjską, która upowszechniała przekazy drukowane i obrazy pokazujące okrucieństwo Niemców ${ }^{62}$. Ludzie przekazywali więc sobie, że żołnierze niemieccy bezczeszczą groby, niszczą kościoły i cerkwie, zrzucają ze stołów Biblię. Ponadto, „Niemcy babom cycki będą obcinać, dzieci nabijać na szable albo wrzucać do studni, starych żywcem wpychać w ogien”, „Mężczyzn będą kastrować”63, mówili mieszkańcy Podlasia, uciekając - często nawet aż na Syberię, Krym i Kaukaz - przed wrogiem ${ }^{64}$.

${ }^{59}$ A. Prymaka-Oniszk, op.cit., s. 27.

${ }^{60}$ Ibidem.

${ }^{61}$ Pomijam teraz bardzo interesującą hipotezę, według której sami Niemcy dążyli do ich rozpowszechniania w celu prowadzenia wojny psychologicznej.

${ }^{62}$ Osobnym zagadnieniem jest celowość wykorzystania plotki wojennej przez propagandę carską. Z pewnością plotkami posługiwano się, by uzasadnić i skłonić do ewakuacji ludność miejscową. Por. K. Sierakowska, Śmierć - wygnanie - głód w dokumentach osobistych. Ziemie polskie w latach Wielkiej Wojny 1914-1918, Warszawa 2015, s. 64-65.

${ }^{63}$ A. Prymaka-Oniszk, op.cit., s. 47.

${ }^{64}$ Tak jak opisana przez Blocha plotka wojenna o złych Belgach została skonstruowana na zestawie kliszy i stereotypów z wojny francusko-pruskiej 1870 roku, tak uruchomiona po zburzeniu Kalisza plotka o dzikich Niemcach była wariantem plotki wojennej z okresu wojny, którą Napoleon prowadził z Rosją w 1812 roku. W tym jej wariancie, co oczywiste, bestiami obcinającymi piersi kobietom byli Francuzi oraz Polacy idący z nimi na Moskwę. Jak pisze Aneta Prymaka-Oniszk, wiemy to, gdyż szczęśliwie do naszych czasów 
W tym samym czasie, kiedy mieszkańcy Kongresówki i Ziem Zabranych podążali na Syberię niesieni histerią i plotką wojenną o szczególnym okrucieństwie Niemców, armia rosyjska wchodziła do zamieszkanej przez Polaków, Żydów i Ukraińców, należącej do Austrii Galicji. Jako obywatele sprzymierzonych z Niemcami Austro-Węgier, mieszkańcy prowincji nie byli skłonni łatwo uwierzyć w plotki wojenne o okrucieństwie niemieckim, zaś wiadomość o zburzeniu Kalisza musiała zostać przyjęta z pewną rezerwą, jeśli wziąć pod uwagę istnienie cenzury wojennej i niewielki dostęp do informacji. Galicjanie zdecydowanie bardziej bali się Rosjan, więc masowy exodus i ewakuacja objęła Polaków i Żydów, a także Rusinów i Ukraińców, którzy uciekając ze wschodu, byli przewożeni na zachód oraz południe ${ }^{65}$.

Interesujące, że z galicyjskich pamiętników i dzienników czasu Wielkiej Wojny, które publikowane były w Polsce po wojnie, istotnie wyłania się obraz zbiorowej histerii. Jest to jednak histeria, której poddali się niemal wyłącznie Żydzi oraz kobiety. Te ostatnie zaś histeria ogarniała niezależnie od klasy, z jakiej pochodziły oraz wykształcenia, o czym donosił dr Jan Hupka, poseł na Sejm Krajowy we Lwowie, pisząc w swoim memuarze: „Pali się o 8 kilometrów od nas odległa wieś Cmolas, gdyż są tam już kozacy. Czuję, że nerwy mych pań już dłużej nie wytrzymają. Postanawiamy wyjechać" ${ }^{66}$. I dwa dni później, 20 września pierwszego roku wojny: „Baby płaczą i ryczą, moje panie także, a i mnie opanowuje wzruszenie" ${ }^{\prime 67}$.

Wspomnienia tego typu, wydawane po wojnie głównie przez mówiących po polsku i dobrze wykształconych mężczyzn, obywateli odrodzonego w 1918 roku państwa polskiego, stały się z jednej strony podstawą dla rodzaju plotki wojennej, której nie uwzględnił w swoich analizach Bloch, z drugiej

zachowały się legendy i plotki wojenne z początku XIX wieku z terenu dzisiejszej Polski wschodniej i zachodniej Białorusi. Spisał je na przełomie XIX i XX wieku etnograf Michał Federowski i zawarł w swoim dziele zatytułowanym Lud białoruski na Rusi Litewskiej. Zob. A. Prymaka-Oniszk, op.cit., s. 47.

${ }^{65}$ Zob. K. Sierakowska, op.cit., s. 153-160. W wypadku ewakuacji i ucieczek galicyjskich Żydów histeria związana z wkroczeniem armii rosyjskiej nie była bezzasadna. Dobrze pamiętano tu bowiem serię pogromów, które wybuchły w rosyjskiej Ukrainie za przyzwoleniem władz w latach osiemdziesiątych XIX wieku i na początku XX wieku, prowadzone zaś były głównie przez Kozaków. Kronikę wypadków antyżydowskich oraz pogromów stworzył Szymon An-ski. Zob. idem, Tragedia Żydów galicyjskich w czasie I wojny światowej. Wrażenia i refleksje z podróży po kraju, przeł. i oprac. K.D. Majus, Przemyśl 2010. Tragiczną konsekwencją żywionego przez władze austriackie przekonania o prorosyjskim nastawieniu ludności ukraińskiej i rusińskiej była natomiast ewakuacja przedstawicieli jej inteligencji i zamknięcie tysięcy ludzi w pierwszym na terenie Europy obozie koncentracyjnym w Talerhof w Austrii. Psychoza strachu spowodowała uwięzienie kilkunastu tysięcy osób i śmierć kilku tysięcy z nich.

${ }^{66}$ J. Hupka, Z czasów wielkiej wojny. Pamiętnik nie kombatanta [sic! - red.], Niwiska 1936, s. 20.

${ }^{67}$ Ibidem. 
zaś pozostawały w zgodzie $\mathrm{z}$ wojenną opowieścią w konwencji „ułańskiego westernu". Można powiedzieć, że zawarty w nich był rodzaj metaplotki czy też plotka o plotce wojennej spreparowana na podstawie fałszywego seksistowskiego, rasistowskiego i klasistowskiego - przekonania, według którego na plotkę wojenną podatne są jedynie pewne niemęskie i niebohaterskie, histeryczne grupy społeczne ${ }^{68}$.

Heteroseksistowska i antysemicka klisza kojarząca histerię z niemęskim, kobiecym charakterem kobiet i Żydów była, o czym już wspominałem, dobrze ugruntowana $\mathrm{w}$ austriackiej publicystyce i teoriach psychologicznych na przełomie XIX i XX wieku. Można więc zaryzykować twierdzenie, że chociaż po wojnie Galicja stała się częścią Polski, piszący mentalnie odnosili się do c. i k. wzorców konceptualizowania histerii, które - jak dobrze się składało - ręka w rękę szły z nowym, ułańskim i westernowym sposobem przedstawiania niedawnej wojny. Plotka o plotce wojennej, jaka została stworzona w powojennej Galicji, łączyła się oczywiście - tak, jak w przypadku twórców fabrykujących obraz bohaterskich ułanów, który zastępować miał wszelkie inne reprezentacje wojny $-\mathrm{z}$ chęcią stworzenia pozytywnego autoportretu. Pamiętnikarze zdawali się mówić, że podczas gdy histeryczne kobiety i Żydzi uciekali w panice, racjonalni i poważni, odważni i mądrzy polscy mężczyźni stali na straży porząaku i ładu. To przekonanie, do którego dołączono austriacką plotkę wojenną o powszechnej ukraińskiej kolaboracji z Rosjanami, wzmocnioną dodatkowo podczas wojny polsko-ukraińskiej o Galicję (1918-1919) i wojny polsko-bolszewickiej (1919-1921), wytwarzało obraz polskiego mężczyzny jako jedynego godnego gospodarza wieloetnicznej i wielokulturowej dawnej Galicji. W ten oto sposób przypisana innym histeria uzasadniała historię, stając się jej dyskursywnym rewersem.

Operacje semantyczne przeprowadzane na wyobrażeniach, jakich używano po wojnie w celu skonstruowania jej przydatnego i koherentnego obrazu, nie zmieniają faktu, że zarówno z cywilnych, jak i żołnierskich pamiętników pisanych przez mężczyzn wyłania się miejscami diametralnie inna wizja historii - jej ukryta, by jeszcze raz przywołać rozpoznania Haydena White'a, histeryczna wersja. W kilku wypadkach mamy do czynienia nie tylko z zapisem skrzętnie skrywanej męskiej histerii wojennej, lecz także z próbą skonstruowania podatnego na plotkę wojenną kobiecego podmiotu histerii sytuowanego w opozycji do męskiego podmiotu historii. Kończąc niniejszy wywód, chciałbym zaprezentować dwa fragmenty mowy histeryków.

Dobrym przykładem sprokurowania obrazu histerycznej kobiety przy jednoczesnej - nieumiejętnej, jak się zaraz okaże - próbie fabrykacji własnego heroicznego konterfektu są wydane w 1930 roku Wspomnienia ks. Kazi-

${ }^{68}$ Por. S. Volkov, Antisemitismus als kultureller Code, München 2000; G.L. Mosse, Nationalism and Sexuality: Respectability and Abnormal Sexuality in Modern Europe, New York 1985. 
mierza Waisa, powojennego rektora Lwowskiego Seminarium Duchownego. Ten przedwojenny jeszcze profesor Uniwersytetu im. Jana Kazimierza we Lwowie pisał następująco:

Tegoż dnia doniesiono mi, że pewna ilość dorosłych dziewcząt, naśladując swe rówieśnice z wsi sąsiednich, zebrała się przed domem miejscowego pisarza gminnego, aby otrzymać od niego legitymację i uciekać przed Moskalami na Węgry. Poszedłem tam i przedstawiłem dziewczętom, że wynosząc się ze wsi, narażają się na jeszcze większe niebezpieczeństwo, że wieści o wszelkich gwałtach moskiewskich są w wysokim stopniu przesadzone, a często nawet zmyślone. [...] Toteż dziewczęta rozeszły się uspokojone do domów ${ }^{69}$.

Opisane przez Waisa w cytowanym fragmencie przyporządkowanie - sobie mądrość i cnota, wiejskim dziewczynom histeria - zaczyna rozpadać się jeszcze na tej samej stronie Wspomnień, kiedy ten rozsądny z pozoru człowiek, jak każe czytelnikom i czytelniczkom o sobie myśleć, daje opis trapiących go myśli. Został on, z pewnością nieświadomie, spisany wzorcową mową histeryka: szybką i charakteryzującą się z pozoru logicznym i realistycznym związkiem przyczynowo-skutkowym:

W nocy [...] szalała solna burza, która mi nie pozwoliła zasnąć. Nie mogłem opędzić się myśli, że gdy jutro rozpocznie się u nas, co było wielce prawdopodobne, walka, natenczas w razie równie prawdopodobnego pożaru, cała wieś spłonie; jeżeliby zaś także mój dom padł ofiarą ognia, nie byłbym bezpieczny w piwnicy, bo z powodu braku żelaznych drzwi u jej głównego wejścia, ogień mógłby się łatwo i do niej dostać. Czy wówczas, pytałem sam siebie, potrafiłbym ogień ugasić, albo czy miałbym czas za pomocą przygotowanych w piwnicy narzędzi zrobić sobie odpowiedni otwór, aby się przezeń dostać na zewnątrz? Obawy moje były tym większe, że w sąsiednim lesie znajdowały się dwa olbrzymie zbiorniki, napełnione ropą. Gdyby który z tych zbiorników eksplodował, a to wśród strzałów łatwo by nastąpić mogło, natenczas zająłby się od niego niewątpliwie las, zaś od lasu wieś, a nadto zapalona ropa płynęłaby wzdłuż wsi korytem rzeki, wobec czego, przy wielkim wietrze, musiałoby przyjść w mgnieniu oka do strasznej katastrofy ${ }^{70}$.

Stanisław Marceli Gayczak to inny wzór męskiej racjonalności. Obraz heroicznego żołnierza i obywatela wyłania się bowiem także z żołnierskiego pamiętnika, jaki powstawał w oblężonym przez Rosjan w 1914 roku Przemyślu, w którym jako żołnierz forteczny służył jego autor. Oberleutnant notuje optymistycznie, acz z niedowierzaniem 26 września: „Pogłoska, jakoby Lwów

${ }^{69}$ K. Wais, Wspomnienia z pierwszego roku wojny światowej, Lwów 1930, s. 31.

${ }^{70}$ Ibidem, s. 31-32. 
był zajęty przez Prusaków (??)’’11 by już 10 października ze zrezygnowaniem zapisać: „Lwów się pali. [...] W duszy wprost rozpaczam. Biedne dzieci moje, biedna Mamusia. Powiadają też, że Bochnia, Rzeszów, Sanok spalone. Boże, Boże, co to będzie! Płakałem rzewnie" 72 . Zapora pęka. 12 października: „Całując fotografię płakałem jak dziecko" "73, 17 października: „Smutno mi, Boże, bardzo smutno!"’74, 25 października: ,Już i płakać nad nimi nie mogę"75, ale już dwa dni później, 27 października: „Zbudziwszy się beczałem pół godziny”76, dzień później, w środę, „zaczynam strasznie płakać”77, a 4 listopada: „rozbeczałem się" Co ciekawe, w ciągu tej istnej powodzi łez, Gayczak zdążył odnotować jeszcze 3 listopada, że ranny kolega Dubaj „wydaje się być wielkim tchórzem”80.

Cytowany powyżej tekst, wydany w całości dopiero sto lat po napisaniu, nie tylko dowodzi, że męska histeria i trauma wojenna nie były zjawiskiem charakterystycznym jedynie dla frontu zachodniego i tego, że cierpieli na nią polscy żołnierze na froncie wschodnim. Być może w wypadku cytowanego tutaj pamiętnika żołnierza mamy do czynienia z niezwykle rzadko uchwytnym na froncie wschodnim, tym bardziej ciekawym i cennym, histerycznym zapisem nerwicy i traumy wywołanej szokiem artyleryjskim.

Jednak w myśl logiki „ułańskiego westernu”, który kazał mężczyznom albo przywdziać ,godowe mundury”, albo milczeć, wydarzenia opowiedziane w relacji z Przemyśla zwyczajnie nie powinny mieć miejsca. Wylane przez Gayczaka morze łez, którym ujście dawał nad swym histerycznym i komicznym zarazem dziennikiem, nie było szczęśliwie dla oficjalnej historii wojennej ani na tyle rozległe, ani głębokie, by stało się dla niej zagrożeniem. Historia zręcznie pozbyła się swojego histerycznego rewersu, ucieleśniając „,prawdę", według której w Galicji płakały kobiety, a histeryzowali Żydzi. Temat nadawał się być może na powojenne Marionetki we Lwowie, z pewnością nie zasługiwał jednak na prasowy anons.

${ }^{71}$ S.M. Gayczak, Pamiętnik oberleutnanta Stanisława Marcelego Gayczaka, Przemyśl 2014, s. 10.

72 Ibidem, s. 13.

${ }^{73}$ Ibidem.

74 Ibidem, s. 15.

${ }^{75}$ Ibidem, s. 17.

${ }^{76}$ Ibidem.

${ }^{77}$ Ibidem, s. 18.

78 Ibidem, s. 21.

79 Ibidem, s. 23.

${ }^{80}$ Ibidem, s. 21. 


\section{Bibliografia}

An-ski S., Tragedia Żydów galicyjskich w czasie I wojny światowej. Wrażenia i refleksje z podróży po kraju, przeł. i oprac. K.D. Majus, Przemyśl 2010.

Bergen L. van, Before My Helpless Sight: Suffering, Dying and Military Medicine on the Western Front, 1914-1918, London-New York 2016.

Bloch M., Rozważania historyka o plotce wojennej [w:] idem, Dziwna klęska, przeł. K. Marczewska, Warszawa 2008.

Branach-Kallas A., Uraz przetrwania. Trauma i polemika z mitem pierwszej wojny światowej w powieści kanadyjskiej, Torun 2014.

Cochet F., „Les Légendes de la guerre” d'Albert Dauzat, un témoignage à chaud des phénomènes de culture collective [w:] A. Dauzat, Légendes, prophéties et superstitions de la Grande Guerre, Paris 2012.

Drozdowski M., Naczelny Komitet Narodowy (1914-1918). Polityczne i organizacyjne zaplecze Legionów Polskich, Kraków 2017.

Echa uroczystości legionowej, „Gazeta Lwowska”, 26.09.1917, nr 219.

Freud S., Aktualne uwagi o wojnie i śmierci, przeł. R. Reszke [w:] idem, Pisma społeczne, przeł. R. Reszke, A. Ochocki, M. Poręba, oprac. R. Reszke, Warszawa 2009.

Gayczak S.M., Pamiętnik oberleutnanta Stanistawa Marcelego Gayczaka, Przemyśl 2014. „Gazeta Lwowska”, 26.09.1917, nr 219.

Henartstan, Marionetki wojenne, Lwów 1917.

Henartstan, Marionetki pokojowe. Trzy akty wesolych piosenek i aktualnych dialogów, Lwów 1917.

Hupka J., Z czasów wielkiej wojny. Pamiętnik nie kombatanta, Niwiska 1936.

Janion M., Wojna i forma [w:] eadem, Płacz generała. Eseje o wojnie, Warszawa 2007.

Jarząbek M., Legioniści i inni. Pamięć zbiorowa weteranów I wojny światowej w Polsce i Czechostowacji okresu międzywojennego, Kraków 2017.

Kaczmarek R., Polacy w armii kajzera na frontach pierwszej wojny światowej, Kraków 2014.

Katalog Wystawy Legionów Polskich. Lwów wrzesień-październik 1917, Lwów 1917.

Lewicki J., Regulacja i odbudowa miast Galicji jako źródło nowoczesnej teorii urbanistycznej w Europie Środkowej [w:] Odbudowy i modernizacje miast historycznych w pierwszej połowie dwudziestego wieku w Europie. Naród, polityka, społeczeństwo, red. I. Barańska, M. Górzyński, Kalisz 2016.

Markowska A., Komedia sublimacji. Granica wspótczesności a etos rzeczywistości w sztuce amerykańskiej, Warszawa 2010.

Micale M.S., Hysterical Man: The Hidden History of Male Nervous Illness, Cambridge 2008.

Milewska W., Zientara M., O ikonografii sztuki legionowej [w:] Przed wielkim jutrem. Sztuka 1905-1918. Materiały Sesji SHS, Warszawa, październik 1990, red. T. Hrankowska, Warszawa 1993.

Milewska W., Zientara M., Sztuka Legionów Polskich i jej twórcy 1914-1918, Kraków 1999. 
Mosse G.L., Nationalism and Sexuality: Respectability and Abnormal Sexuality in Modern Europe, New York 1985.

Nałęcz T., Pokolenie Józefa Piłsudskiego [w:] Legenda Legionów. Opowieść o Legionach oraz ludziach Józefa Pitsudskiego, red. W. Sienkiewicz, Warszawa 2008.

„,Niemiecki Wschód”. Wyobrażenia - misja - dziedzictwo, wyb. i oprac. Ch. Klessmann przeł. I. Drozdowska-Broering, J. Kałążny, Poznań 2014.

Pol W., Kłopot pannom z czwartakami [w:] idem, Pieśni Janusza, Kraków 1921.

Prymaka-Oniszk A., Bieżeństwo 1915. Zapomniani uchodźcy, Wołowiec 2016.

Showalter E., The Female Malady: Women, Madness and English Culture, 1830-1980, London 1987.

Sierakowska K., Śmierć - wygnanie - głód w dokumentach osobistych. Ziemie polskie w latach Wielkiej Wojny 1914-1918, Warszawa 2015.

Stępnik K., Rekonesans. Studia z literatury i publicystyki okresu I wojny światowej, Lublin 1997.

Szczepaniak M., Habitus żolnierski w literaturze i kulturze polskiej w kontekście Wielkiej Wojny, Kraków 2017.

Szymański W., Images from the Eastern Front. Great Returns or Death among Old Decorations? Remarks on Representation of the Great War in Polish Art [w:] Conflicting Discourses, Competing Memories: Commemorating the First World War, red. A. Branach-Kallas, N. Sabiniarz, N. Strehlau, Torun 2015.

Szymański W., „,Modi memorandi”. Pamiętanie i przeżywanie Wielkiej Wojny wtedy i dzisiaj. Próba komparatystyczna, „Litteraria Copernicana” 2018, nr 3 (27).

Szymański W., Zagubiona stracona generacja. Sztuka polska wobec Wielkiej Wojny jako przeżycia pokoleniowego [w:] Wielka Wojna, red. P. Kurc-Maj, P. Polit, A. Saciuk-Gąsowska, Łódź 2018.

Śmieja W., Hegemonia i trauma. Literatura wobec dominujących fikcji męskości, Warszawa 2016.

Traba R., Zapomniana wojna. Wydarzenia lat 1914-1918 w polskiej i niemieckiej pamięci zbiorowej [w:] Polacy i Niemcy. Historia - kultura-polityka, red. A. Lawaty, H. Orłowski, Poznań 2003.

Volkov S., Antisemitismus als kultureller Code, München 2000.

Volkov S., Antysemityzm i antyfeminizm. Norma spoleczna czy kod kulturowy? [w:] eadem, Pomyst na nowoczesność. Żydzi niemieccy $w$ XIX $i$ na początku XX wieku, przeł. J. Górny, P. Pieńkowska, Warszawa 2006.

Wais K., Wspomnienia z pierwszego roku wojny światowej, Lwów 1930.

White H., Zdarzenie historyczne, przeł. R. Borysławski [w:] idem, Proza historyczna, red. E. Domańska, Kraków 2009.

Wyganowska W., Sztuka Legionów Polskich 1914-1918, Warszawa 1994. 